\title{
ПОЧАТКИ ЦИРКОВОГО МИСТЕЦТВА НА ЗАХІДНОУКРАЇНСЬКИХ ЗЕМЛЯХ У СКЛАДІ ІМПЕРІї ГАБСБУРГІВ
}

\begin{abstract}
У статті досліджується проиес становлення ииркового мистецтва на західноукраїнських землях у складі імперії Габсбургів кіния XVIII - початку XIX cm. На основі матеріалів преси досліджуваного періоду описуються циркові трупи та артисти, які відвідали з гастролями Львів та Чернівиі в 20-30-ті рр. ХIX cm., їх артистичний склад і репертуар; зроблено спробу аналізу сприйняттяя у суспільстві циркових і театрально-видовищних вистав і визначення їх статусу та місия в культурному просторі того часу.

Ключові слова: ииркове мистеитво, менажерія, ииркові найзники, акробати, атлети, статус ииркового мистецтва, Галичина, Львів, Чернівиі.
\end{abstract}

В статье исследуется прочесс становления ииркового искусства на западно-украинских землях в составе империи Габсбургов кониа XVIII - начала XIX в. На основе материалов прессы исследуемого периода описываются трупы посетившие с гастролями Львов и Черновиы в 20-30-е гг. ХІХ в., их артистический состав и репертуар; сделана попытка анализа восприятия в обществе цирковых и театрально-зрелищных представлений и определения их статуса и места в культурном пространстве того времени.

Ключевые слова: иирковое искусство, менажерия, цирковые наездники, акробаты, атлеты, статус ииркового искусства, Галиция, Львов, Черновиьь.

In the article, the process of the formation of circus arts in the Western Ukrainian lands of the late eighteenth and early nineteenth centuries, during the time that they were a part of the Habsburg Empire, is researched. Based on the materials of the press of the studied period, it describes the troupes which visited Lviv and Chernivtsi in the 20-th and 30-th years of the nineteenth century, and their artistic cast and repertoire. An attempt was made to analyze the perception in the society of circus performances, and to determine their status and place in the cultural space of that time.

Key words: circus, menagerie, circus riders, acrobats, athletes, Galicia, status of circus, Lviv, Chernivtsi.

У другій половині XVIII - на початку XIX ст. на етнічних територіях України почали з'являтися перші професіональні трупи майстерних наїзників, акробатів, атлетів, ілюзіоністів, дресирувальників із Західної Європи, — ті, кого сьогодні ми називаємо «артистами цирку», а розмаїття їх умінь і жанри, в яких вони виступали, в XX ст. об'єднали у поняття «циркове мистецтво». Поділені між двома імперіями, українські простори стали благодатним грунтом для укорінення початків циркового мистецтва та його подальшого розвитку. Циркові виступи в українських містах у складі Російської імперії знайшли відображення у низці наукових досліджень радянських та сучасних українських авторів. В цьому сенсі особливий дослідницький інтерес викликає маловідомий аспект розвитку циркового мистецтва на західноукраїнських землях у складі Австро-Угорської імперії, який досі залишався поза належною увагою науковців.
Матеріали львівської, чернівецької та віденської преси XIX - початку XX ст. містять цінні відомості про виступи в Галичині та Буковині визначних циркових труп і відомих свого часу артистів. Дані ці, втім, вимагають систематизації, перекладу і $є$ унікальною основою для простеження та аналізу розвитку циркового мистецтва на західноукраїнських землях. Таку мету поставлено автором цієї статті, завданням якої є визначення особливостей початкового періоду гастрольної діяльності циркових труп в Західній Україні, що припадає на першу третину XIX ст.

Єдиним дослідженням, яке зачіпає тему цирку в Галичині, є стаття Барбари Ласоцької, присвячена виступам акробатів, магів та панорамам у Львові першої половини XIX ст., написана в 1960-ті pp. і надрукована у польському театральному журналі [26]. Дані цієї статті згодом слугували допоміжним матеріалом для досліджень історії цирку на тери- 
торії Польщі, зокрема, книги польського історика Яніни Хери [23]. 2017 року в Польщі вийшла друком книга «Цирк в світі видовищ» [2], в якій фрагментарно згадуються циркові виступи у Львові.

У порівнянні зі спробами попередників, у пропонованій статті розширено джерельну базу, для аналізу використано газетні публікації та рекламні циркові афіші досліджуваного періоду з музеїв і бібліотек Німеччини, Польщі, Австрії, Голландії, США.

Перша документована згадка про акробатичні виступи у Львові відноситься до 1770-1780-х років. 1840 року до рук кореспондентів «Gazeta Lwowska» випадково потрапила афіша, яка запрошувала львів' ян на відвідини «комедії від славного Ангельчика»: передбачався виступ з небаченими до цього різноманітними вправами на дроті та канаті, показ пантоміми під назвою «Лукавий Арлекін», механічний феєрверк, який мав відобразити Версальський сад, а також вогняне шоу. Акробатично-магічна вистава відбувалася у приміщенні Гетьманської кам'яниці, колишній садибі польського короля Яна III Собеського. Час друку афіші було визначено приблизно, виходячи з техніки друкування, адже саме такими були книги, які друкувалися у Львові в 1770-1780-х рр. [56, 99]. Імовірно, подібні театрально-видовищні вистави могли відбуватися і раніше, але документальних підтверджень цьому наразі немає.

На території імперії Габсбургів ліноскоки та інші подорожуючі комедіанти розважали як аристократію, так і решту населення ще в XVII ст. [62, 103]. Визначення «Seiltänzer» (канатний танцівник) в ті часи було узагальнюючим для акробатичних жанрів. Таке формулювання в середині XVIII ст. містилося в державних правилах і законах Імперії, де акробатам були присвячені окремі параграфи $[58,712,817]$.

Цирк, який ми знаємо сьогодні, датується приблизно 1770 роком, коли Філіп Естлі, англійський сержант та інструктор з верхової їзди, побудував у Лондоні невелику арену і представив публіці виступи наїзників, балансерів на канаті, акробатів, стрибунів, жонглерів, клоунів $[62,7]$.

Виступи на манежі цирку сприяли естетизації виступів комедіантів, які отримали «місце проживання» для своїх «мистецтв». Цирк надавав акробатичним номерам більш культурну форму, а вони наповнювали циркові програми різноманітністю та змістом. На вищий щабель піднімався соціальний статус виконавців.

Дослідник театральної культури Львова Станіслав Шнюр-Пепловський писав про перебування у Львові взимку 1795 року великого звіринця та мандрівного цирку, в котрому, окрім самих виступів, багата молодь брала уроки кінної їзди $[61,38]$.

У Галичині відбувався процес розвитку видовищних показів і поступовий перехід від виступів мандрівних комедіантів до гастролей професіональних майстрів цирку.

У наступні 50 років після перших вистав Естлі цирк поширювався в Європі $[62,7]$.

Початок професіональних циркових виступів в Австрії пов'язаний з ім'ям наїзника Крістофа де Баха $[62,103]$. В листопаді 1808 року віденська газета сповіщала про відкриття у Пратері, улюбленому парку та розважальному центрі Відня, стаціонарного Гімнастичного Цирку: «У Відні знаменитий наїзник Крістоф де Бах відкрив Гімнастичний Цирк. Цей цирк в Пратері побудований в стилі древніх цирків, але має повне накриття. Це - ротонда з вестибюлем, яка отримує світло через купол. Всередині амфітеатр побудований з великим смаком» [24, 677-678]. До середини XIX століття Гімнастичний Цирк був провідною ареною Австро-Угорської імперії.

На початку 1810-х рр. Крістоф де Бах виступав у Львові. Про це писалося 1842 року в статті присвяченій львівським гастролям Олімпійського Цирку Алесандро Гверри, в якій автор пригадав виступи визначних товариств наїзників у Львові протягом попередніх 30 років: де Баха з Відня, Турнієра, Стефані, Вольфа, Кенебеля [20, 281-282].

Основою циркових труп у першій половині XIX ст. були династії наїзників, в яких майстерність передавалася 3 покоління в покоління, а на аренах поряд 3 дорослими виступали дітлахи, демонструючи найскладніші вправи на конях. В німецько- та польськомовних джерелах того часу вправи наїзників визначалися як «мистецтво майстрів верхової їзди», а їх трупи, як «товариства майстерних наїзників» (нім. Kunstreiter Gesellschaft; пол. Towarzystwo Sztucznych Jeźdźców). Німецька енциклопедія, видана у Відні 1829 року, визначала майстерну верхову їзду як основу тогочасної гімнастики і називала серед провідних артистичних товариств - Естлі в Лондоні та Франконі в Парижі, а також де Баха, Турнієра, Блондіна, Стефані та Кьяріні $[54,485]$. Виступи майстерних наїзників сприяли значній зацікавленості цирковими виставами привілейованих верств Свропи. В той період верхова їзда була частиною повсякденного життя, коні використовувалися для пересування, полювання, кавалерія була військовою елітою. На циркових аренах демонструвалися пантоміми на історичні теми, в яких наїзники виступали в героїчних об- 
разах, на іподромах відбувалися перегони на колісницях, які нагадували про змагання та вистави часів Стародавнього Риму. Поширення історичних пантомім і їх популярність, особливо після періоду наполеонівських війн, пов’ язані з формуванням національних історій. Простір манежу і майстерність наїзників давали змогу здійснювати масштабні постановки з вражаючими декораціями, масовими сценами, карколомними трюками, відтворюючи сюжети з історичного минулого. Відзначивши загальноєвропейське захоплення кінними виставами, Б. Ласоцька метафорично назвала перші гастролі товариств наїзників у Львові «кінською інвазією» [26, 139].

В пресі кінця 1810-х рр. трапляються відомості про функціонування у Львові «Школи верхової їзди Ранца» (нім. Ranzischen Reitschule), яка розміщувалась в Сзуїтському Саду (в наш час-Парк ім. Ів. Франка). Споруду цю на початку XIX ст. побудував «титулований професор» верхової їзди Йозеф Крупп (Józef Krupp), а 1810 року її придбав Валенті Ранц (Walenty Ranc). Це приміщення було довгим і відносно низьким; у першій половині XIX ст. воно стало місцем для виступів циркових труп, які відвідували з гастролями місто $[61,98]$.

Також 1818 року писали, що на продаж було виставлено приватний будинок зі стайнею і школою верхової їди графа Ксав'є Старзенського [28, 228].

3 початку 1820-х рр. циркові виступи у Львові починали регулярно висвітлюватися у пресі.

У серпні 1819 р. в Єзуїтському Саду, «львівському Пратері», виступала гімнастична трупа Козак і Фенеролі. Стрибки у їх виконанні були сміливими, мадам Козак була особливо вправною на дроті. Їх вистави постійно користувались високим попитом. Артисти приваблювали публіку, пересуваючись містом в африканському вбранні, на високих ходулях $[63,380]$. У жовтні у Школі верхової їзди Ранца з великим успіхом показала верхову їзду, акробатичні стрибки та вправи на канаті сімейна трупа Коен (die Familie Cogen) з Парижа (?!) [64, 572]. Дослідник австрійського театру у Львові Сжи Гот відзначав надзвичайну популярність акробатичних виступів серед львів'ян у цей період $[21,208]$.

У липні 1825 року шанувальники гімнастичних вистав насолоджувались виступами росіянина П. Іванєвича (P. Iwaniewicza Rossyianina), який називав себе «учнем Пінетті» (?) [56, 216]. У серпні 1821 року «Школа верхової їзди» 3 18-ма кіньми та зручними помешканнями запрошувала охочих до навчання наїзницькій майстерності. [29, 510]. Верховою їздою захоплювались вельможні й багаті громадяни.
Влітку 1823 року подією державного масштабу став візит до Львова ерцгерцога Австрійського Франца Карла Габсбурга. В цей же час у Львові виступала одна з провідних труп наїзників першої третини XIX ст. під керівництвом Жака Турнієра. Так, численна аудиторія, яка зібралася на виставі 18 липня 1823 року, удостоїлася честі бачити присутність «його Високості» [30, 389], а за тиждень трупа Турнієра взяла участь в організованому місцевими землевласниками Фестивалі Врожаю в парку Погулянка, де також був присутній ерцгерцог. Велика карусель вершників Турнієра завершувала розважальну програму фестивалю, котра складалася 3 національних танців, ігор та розваг [31, 405]. Ще за кілька днів ерцгерцог знову відвідав виступ Цирку Турнієра [32, 417]. На арені майстерність у кінних вправах демонстрували Луї Фуро, сини Жака Турнієра Бенуа та малий Франсуа Турнієри, дочка Софі Елоїза, (у заміжжі — пані Фуро). Виступи відзначалися смаком і пишністю костюмів [20, 281-282].

У серпні 1825 року у Львові гастролював «Гімнастичний Цирк» Йозефа Готьє, наїзника, який два роки тому виступав у складі трупи Жака Турнієра. Цього разу Готьє очолював власну трупу канатоходців та наїзників. В програмі демонструвалися також стрибки на батуті. Трупа виступала з великим успіхом [33, 483].

Взимку 1825-1826 рр. Львів відвідала сімейна трупа наїзника Людвіга Кенебеля. Газета писала, що сміливість і безстрашність Кенебеля, легкість i спритність на конях навряд чи будуть перевершені. Урізноманітнювали виставу граціозні виступи дружини Кенебеля та «чарівна солодкість» маленької доньки Віргінії. В складі трупи Кенебеля виступали виконавець рідкісних номерів на натягнутих та провисаючих канатах п. Мустафа і клоун (Bajazzo) 3 трупи Гертнера [34, 774].

У березні 1826 року до Львова завітав «Олімпійський Цирк», трупа наїзників, вольтижерів, стрибунів на батуті з 36 дресированими кіньми під керівництвом Петера Стефані. Реклама у львівській газеті представляла трупу Стефані як «Академію вищої школи верхової їзди» $[35,126]$. Програма виступів у Цирку, що розміщувався в Єзуїтському Саду, змінювалася щоденно, інформація про зміни містилася на спеціальних друкованих афішах [36, 174]. У травні трупа Стефані зробила невелику перерву у виступах і готувала показ масштабних пантомімічних вистав на історичну тематику. Це — «Битва при Кульмі» та «Гора Везувій біля Неаполя» [39, 280]. Через брак простору у приміщенні помпезні покази відбувалися в Сзуїтському Саду просто неба 
[40, 296]. Стефані першим представив львів'янам історичні пантоміми з масовими сценами, подібні до тих, які демонструвалися в Амфітеатрі Естлі та Олімпійському Цирку Франконі в Парижі, адже виступи у Львові попередників - труп Турнієра, Кенебеля та Готьє — обмежувалися верховою їздою, невеликими сценами за участі десятка артистів, вправами на канаті та стрибками на батуті.

Під час гастролей у Львова Петер Стефані раптово помер. Виступи трупи продовжувались під керівництвом його вдови Софії Стефані. У трупі виділялися наїзник на прізвисько «Американець» та П. Прайс. Їх відвага була на найвищому рівні: перший демонстрував впевненість і силу, другий прагнув виконати все найретельніше. Американець з незрівнянною майстерністю виконував вольтижування, Прайс на шаленій швидкості сміливо скакав без вуздечки на трьох і чотирьох конях. Однакової похвали заслуговували також Пані Дункель, Панна Адалі, пп. Модест, Юзеф, Чарі та інші [57, 227].

Наприкінці березня 1826 року до Львова приїхав загадковий майстер ілюзії з Туріна Бартоломео Боско, який перед цим з великим успіхом демонстрував свої механічно-фізичні вистави в багатьох містах Європи. Перед гастролями у Львові Боско здивував королівську родину в Берліні, а наразі повертався з Санкт-Петербурга, де він виступив перед імператорською сім'єю, міністрами і поважними громадянами $[19,410]$.

Львівська публіка з захопленням відвідувала вистави Боско, і вже після перших виступів в місцевому «Redoutensaal» він здобув суспільне визнання. Газета писала, що «його виступи далекі від шарлатанства, він демонструє майстерність 3 пристойністю та гідністю, як справжній артист. Важко уявити більш досконалий рівень майстерності, продемонстрований голими руками. Такі майстри мають виступати у Львові частіше і якомога більше шанувальників цього мистецтва мають відвідати виступ Боско» $[37,195]$.

Сам Боско через газетні оголошення запрошував львів'ян відвідувати вистави і обіцяв дивувати, перевершуючи вже продемонстроване раніше, хизуючись великим успіхом попередніх виступів у європейських столицях. Він анонсував новий показ, під час якого «дванадцять солдатів мають зарядити кулями рушниці в кінці залу і вистрілити в Боско, який знаходитиметься на протилежному кінці. Він спіймає всі дванадцять куль однією рукою і продемонструє їх у долоні публіці. Навіть ті, хто вважає такий трюк небезпечним, не повинні нервувати, адже артист впевнений в успіху і це жодним чином не зашкодить ані йому, ані присутнім в залі» [38, 245-246].

Виступи Боско були настільки успішними, що він кілька разів відкладав від’ізд, аби задовольнити побажання публіки новими виставами [40, 295]. I, навіть залишивши Львів у червні 1826 р., повернувся знову у жовтні після виступів у Яссах, щоб дати ще кілька вистав $[42,632]$.

Регулювання діяльності циркових артистів було прописано в «Провінційній Збірці Законів Королівства Галіції і Лодомерії» 1827 року. Так, для виступів у Львові акробатам потрібно було мати дійсний паспорт і отримати дозвіл на виступи в управлінні поліції. Артистична діяльність прирівнювалася до торгівлі і підлягала оподаткуванню залежно від розмірів отриманих доходів [22, 214-217].

3 середини 1820 -х рр. Львів регулярно відвідували звіринці (менажерії), концепція яких передбачала поєднання «зоопарку» та дресури диких звірів. В уяві публіки це відтворювало романтичну атмосферу далеких екзотичних заморських країв.

Першим до Львова приїздив у березні 1827 року Голанський Звіринець п. Ван Дінтера. Власник запевняв, що живі змії, земноводні та ссавці, зібрані завдяки великим зусиллям та витратам в Азії, Африці та Індії, привезені в Свропу капітанами Джорджем Блоу та Фредеріком Хамондом. Їх вже з захопленням бачили Імператор та Ерцгерцог Австрійський, Король Прусський в Берліні, Його Величність Король Саксонії в Замку Пілнітц, баварська королівська родина в Мюнхені. Програма показу включала приборкання смугастої гієни, дикого, хитрого і лютого хижака, яке є можливим лише завдяки наполегливості й терпінню приборкувача. Крім того, Ван Дінтер обіцяв увійти в клітку до трьох левів і левиці і довести, що приборкання цих хижаків може бути успішним. Також були продемонстровані великий удав та два леопарди [43, 145-146]. Менажерія Ван Дінтера дивувала львів'ян протягом майже місяця [44, 199].

1829 року директор львівської Реальної Школи та краєзнавець Алоїз Уле писав, що наприкінці 1820-х рр. у львівському уряді обговорювалися плани будівництва стаціонарного приміщення для гімнастичних виступів та менажерій на місці колишнього «нижнього Замку» (niedere Schloß), на площі між будівлею Університету, Педагогічним Училищем, Краківським м'ясним ринком та річкою Полтва. Цирк був необхідним у місті, зважаючи на часті гастролі, а будівля Школи верхової їзди, де зазвичай відбувалися подібні виступи, знаходилася в незручному місці. За розпорядженням Губернської Ради (Gubernialrath) площу було розчищено, 
навколо майбутнього цирку планувалося розбити сад. Проте, оскільки міській громаді знадобилися кошти для будівництва Ратуші, приведену до ладу площу по частинах спродали під приватну забудову, і план будівництва цирку не був реалізований [18, 719-720].

1830 року в приміщенні будинку Креппа львів'ян дивували зміями та крокодилами Томас Гюлі і Шмідт. Гримучу змію та алігаторів до Львова привезли вперше [45, 134]. Ще за 4 роки, в січні 1834 року, Менажерія Россі демонструвала вишукано-гарну велику пантеру, прекрасну смугасту гієну, красивого трансільванського ведмедя, американського дикобраза, великого і сильного вовка з Норвегії, великого білого пелікана, різних папуг $[46,19]$.

Навесні 1834 року у Львові потерпав від негоди «Cirque olympique» Гайнріха Вольфа з Берліна. Суворий, морозно-холодний вітер завдав руйнувань дерев'яному амфітеатру, який мав повне накриття. Газета писала, що «виступи наїзників були сміливими, в них відчувалося щось "дитяче", та хоча сама ідея залишалося популярною, проте вже втрачала прихильників» [60, 398]. У вересні трупа Вольфа залишила Львів і вирушила до Константинополя. Під час виступів, у трупі виділявся акробат п. Стелла. Достойними бути включеними до біографічних словників, на думку львівського доповідача на ім'я Амікус, також були артисти Жоко та Консортен $[61,674]$.

У вересні у Львові анонсувався скорий приїзд до міста Театру Мавп Гайнріха Шрейєра з Відня. Сам директор звертався до львів'ян, обіцяючи здивувати слухняністю чотирилапих артистів, яким вже аплодувала публіка найбільших міст Свропи [47, 544]. За місяць сповіщалося про успішні виступи трупи, в якій артисти не отримували гонорарів, не вимагали бенефісів, годувалися і розміщувалися наймачем, при цьому віртуозно грали на фортепіано чотирма руками, а також на кількох найдревніших інструментах. У Львові це товариство стало улюбленцем публіки, як і в будь-якому місті, де воно виступало раніше. Навіть маленька трупа майстерних наїзників, яка в цей же час виступала у Львові, не могла успішно конкурувати з Театром Мавп $[25,1046]$. Сам підприємець заслуговував всілякої похвали, влаштувавши життя цих тварин так, щоб вони виявляли таку вражаючу майстерність у виконанні своїх чудових трюків. Гардероб був доречним і підібраним зі смаком, сам театр досить красиво оздобленим, машинерія була в порядку, дія відбувалася швидко і не переривалася нудними паузами, грав живий оркестр. Зала була завжди повною $[4,3]$.
В середині 30-х pp. XIX ст. популярності набували виступи на театральних сценах атлетичних та акробатичних труп. Мистецьке видання «Mnemosyne» писало, що «в 1835-1840 pр., за часів директорства п. Нойфельда, на сцені міського театру Львова виступили канатоходці Далло, Фуро, «геркулеси» Раппо, Дюпюї, відомий мім Клішніг» $[52,140]$. Англієць Едуард Клішніг був визнаним майстром у новому жанрі, який на честь нього отримав назву «клішнік». У театральних постановках він демонстрував гнучкість, пластичність, м'якість тіла, майстерно перевтілюючись в образи мавпи та жаби [55]. Насправді, у Львові 1837 року виступав не Едуард Клішніг, а інший артист на ім'я Луї Далло, який зіграв роль Мавпи у виставі Нестроя «Мавпа і наречений» $\mathrm{i}$ «дав чітке уявлення про те, що робив п. Клішніг» $[17,88]$. Сам Едуард Клішніг виступив у Львові 1857 року на сцені Театру гр. Скарбека $[27,1]$.

Наприкінці 1835 року у міському театрі Львова виступала сімейна акробатична трупа Далло з Франції $[5,3]$. Генрік Далло, «перший канатоходець Театру мадам Сакі в Парижі» збирав повні зали і зробив сенсацію у Львові своїми майстерними виступами на мотузці $[6,4]$. Далі Далло вирушав до Чернівців, плануючи відвідати Станіславів та Броди. Виступи його настільки сподобалися львів'янам, що навесні у Львові чекали на повернення майстра [7, 3-4]. Не менш вдало Далло виступив у школі верхової їзди в Чернівцях. Легкість, з якою він виконував найскладніші і найнебезпечніші стрибки, викликала здивування. Також вражала майстерність дружини Генріка мадам Далло та маленького сина Августа [9, 4]. Влітку 1836 року Далло повернувся до Львова. 3 липня Єзуїтський Сад перетворився на паризький Тіволі: Далло поєднав свої виступи з феєрверком, та, незважаючи на загрозливі хмари, цирк був заповнений і публіка повністю задоволена $[11,4]$.

Навесні 1836 року у львівській «Школі Верхової Їзди Ранца» «гімнастичну силову виставу» показували атлет Жан Дюпюї на прізвисько «Незрівнянний» та «єдина в світі» жінка надзвичайної сили, «Жінка-Геркулес» (нім. Herkulesin) пані Тойч. Одним з атракціонів в програмі була «римська боротьба». Дюпюї мірявся силою з охочими позмагатися за чималий грошовий приз у 1000 флоринів. Через оголошення в газеті артист запрошував претендентів особисто 3'явитися в готель, де він зупинився (Hotel de Russie Nr. 14) і залишити свою адресу та ім'я [48, 98]. Виклик прийняв відомий своєю силою, двадцятивосьмирічний львів'янин Йоганн Хоффманн, який досі не зазнавав поразок у боротьбі $[49,101]$. 1 березня відбувався поєдинок. Здавалося успіх 
був на боці Хоффманна, як раптом він опинився на спині на підлозі і програв бій $[3,120]$. Влітку Дюпюї та п. Тойч показували «силові вистави» в міському театрі Чернівців. Відбувалися і змагання 3 боротьби. Кореспондент припустив, що «Дюпюї використовував підсадного компаньйона, сила якого не претендувала на призові 1000 флоринів, і якого бачили під час змагань у трьох містах». Директор театру п. Нойберт докладав великих зусиль для залучення глядачів, проте чернівчани залишили виступи Дюпюї поза увагою. [9, 4].

У червні 1836 року у Львові гастролював великий звіринець 3. Політо. Покази відбувалися в Цирку п. Майєра в Єзуїтському Саду [50, 296].

1834 року у Відні помер Крістоф де Бах, і власницею Гімнастичного Цирку стала його дружина Лаура де Бах, наїзниця та балерина, яка активно взялася до продовження циркової справи в партнерстві з французьким наїзником Луї Сульє, $з$ яким вона невдовзі взяла шлюб [57, 12-13].

Влітку 1836 року газети сповіщали про скорий приїзд трупи мадам де Бах до Львова, для чого в Єзуїтському Саду спеціально споруджували новий цирк $[10,4]$. Подорожуючи з Відня до Львова, трупа з великим успіхом виступала в містах Імперії. Тим часом у Львові, за винятком кількох прикрас та елементів внутрішнього декору, було майже завершено будівництво нового цирку-амфітеатру, який мав забезпечити максимальний комфорт публіці $[12,4] .23$ серпня 1836 року відбувся перший довгоочікуваний виступ у новозбудованому цирку у Львові $[13,4]$.

Невдовзі львівська преса анонсувала небачені до цього перегони на конях та римських колісницях у виконанні майстрів трупи де Бах, подібні до тих, які були показані 1834 року у віденському Бельведері [51, 480]. 25 вересня 1836 року у Львові відбулися «Великі амфітеатральні кінні перегони». Це видовище Лаура де Бах і Луї Сульє підготували як демонстрацію продовження традицій перших Олімпійських Ігор 776 року до н.е. та змагань, які в античні часи відбувалися на численних аренах Греції та Риму. До участі в перегонах Сульє запрошував львів'ян з власними кіньми, охочі мали заздалегідь попередити його особисто про участь. Товариство обіцяло забезпечити учасників яскравими костюмами та виставити на загальний огляд нагороди та прапори майбутніх переможців [52, 491-492].

Програма вистави розпочиналася з великої презентації всіх членів трупи, потім мали відбутися кінні перегони двох дітей, кінні перегони трьох листонош, великі перегони без сідел, перегони двох наїзниць - Нанет Гері і Амалії Гаспаріні, перего- ни чотирьох англійських жокеїв. Потім великий незвичайний заїзд на сімох неосідланих конях мав здійснити сам Луї Сульє. За 4 хвилини 2 секунди він повинен був тричі об'їхати велику арену, подолавши найбільший бар'єр. Перше відділення мали завершити перегони двох жокеїв-переможців. У другому відділенні відбувалися мальовничі перегони на трьох давньоримських бігах (колісницях). Далі газета сповіщала, що найближчим часом до трупи мав приєднатися комічний наїзник, улюбленець віденської публіки Луї Далло, який завершував виступи в Берліні. Дирекція в особі Л. Сульє і Л. Де Бах робила все можливе для задоволення шановної львівської публіки [52, 491-492].

У Львові відбулося 37 вистав, які мали великий успіх. Далі трупа прямувала до Константинополя, плануючи відвідати Чернівці, Ясси, Бухарест $[14,4]$.

Наприкінці листопада 1836 р. трупа Сульє-де Бах завітала до Чернівців. Серед наїзників особливо вирізнялися, окрім самого п. Сульє, також пп. Кокі, Кеглієні та Альберт де Бах [15, 4]. Але за місяць віденська газета розчаровано сповіщала, що в Чернівцях відбулося лише 11 вистав, і виступи мали найменший інтерес у порівнянні з будь-яким іншим містом. На п'яту виставу прийшло лише 20 глядачів, тож іiї відмінили. Більш популярним у місті був театр, на чолі якого стояв п. Сеусерт $[16,4]$.

Досліджуючи акробатично-магічні та пантомімічні вистави в Україні кінця XVIII-початку XIX ст., Кость Копержинський дійшов висновку, що «виступи ліноскоків та фіглярів в свідомості глядачів у цей період сприймалися не як твір мистецтва, а як видовище, і були, власне, не цирковим видовищем, а театральною виставою» $[1,61]$. Галичина в першій половині XIX ст. переживала спалах культурного розвитку, і одним з його виявів стали часті гастролі провідних майстрів цирку, які водночас були і культурними подіями, і вишуканою розвагою. Їх із захопленням описували провідні газети, спеціалізовані мистецькі видання, в яких рецензії на циркові вистави містилися поряд з відгуками про театральні постановки, новинами літератури; для характеристики виступів гімнастів, магів та наїзників у тогочасних друкованих джерелах постійним було використання морфем «kunst» (мистецтво, мистецький) «künstlerisch» (художній). Німецька Енциклопедія 1829 року, визначаючи «мистецтво» (Kunst) як те, «що випливає з майстерності», відносила до «красних мистецтв простору і часу» пантоміму (Mimik), танець (Tanzkunst) та акторську гру (Schauspielkunst) [54, 481-482]. Елементи цих мистецьких категорій можна знайти і в історичних пантомімах, і в акробатичних номерах (танцях) на 
канаті, і в пластичних виставах Едуарда Клішніга, якого німецькі видання визначали, як міма, імітатора (Mimiker), та його наслідувачів і послідовників, і в механічно-фізичних виставах Бартоломео Боско.

Серед особливостей досліджуваного періоду слід відзначити:

1) Саму по собі новизну явища гастрольної діяльності професіональних циркових труп, які ще тільки починали подорожувати містами Свропи. Театральні трупи активно застосовували гастрольну практику, і перейняття цього досвіду значно розширило творчі можливості цирків. Зважаючи на те, що циркові наїзники, акробати довго відпрацьовували обмежений набір трюків і показ вистав в межах одного, навіть великого міста швидко вичерпував їх потенціал і можливості, гастрольна практика ідеально відповідала специфіці цирку.

2) Будівницттво спецііальних «цииркових» приміщзень. В Австро-Угорщині початку ХІХ ст. існував лише один стаціонарний «Circus Gymnasticus» у віденському Пратері. Наїзники, під час гастролей в містах Імперії, виступали або в популярних в ті часи школах верхової їзди, або в тимчасових дерев'яних цирках. Хоча методи їх будівництва постійно вдосконалювались, значною перешкодою для виступів ставала холодна пора року. Циркові трупи змушені були робити перерви у виступах, бо вистави взимку ставали справжнім випробуванням і для виконавців, і для публіки. 1834 року негода зіпсувала гастролі Олімпійського цирку Вольфа i, можливо, була однією з причин невдалих гастролей цирку Л. Сульє та Л. де Бах в грудні 1836 року в Чернівцях.

3) Мультикультуризм. У багатонаціональній i різномовній Австро-Угорщині, особливо після нещодавніх поділів Польщі, природно, виникали національні суперечності. В цих умовах цирк, 3 його інтернаціональним складом труп та легкістю сприйняття вистав публікою, відігравав об’єднуючу і миротворчу роль.

4) Увага спеціалізованої та публічної міської преси. Через недостатню кількість розваг і інших видовищ, ефектні, яскраві, екзотичні виступи циркових майстрів, природно, викликали підвищений інтерес публіки і отримували відповідне відображення на сторінках газет. Свою справу робила i якісна реклама в пресі, яка гідно представляла митців публіці. Люди жадали побачити те, чим захоплювались європейські монархи.

Віденські газети ретельно відстежували циркові гастролі у провідних містах Свропи, приділяючи увагу і Львову. Можна констатувати синхронність загальноєвропейського розвитку циркового мис- тецтва і помітне місце галицької столиці в ієрархії тогочасних культурних осередків.

5) Емпіричність - відсутність системної освіти, спеціальної «циркової» термінології, невизначеність жанрів, їх поступовий розвиток i урізноманітнення, рух від трюкових виступів наїзників, кінних перегонів, історичних пантомім, акробатично-гімнастичних, атлетичних, магічних вистав у напрямку умовного об'єднуючого поняття «циркове мистецтво».

6) Дуалізм (подвійність), — «розсіювання» виступів між сценою та ареною. Через одночасну невизначеність статусу та популярність «циркові мистецтва» поширювались і стверджувались як на манежах цирків, так і в театральних залах. Директори театрів запрошували до виступів акробатів і навіть наїзників (!) для залучення публіки, яка погано відвідувала драматичні вистави.

7) Конкуренція. Попри впевненість у тому, що «публіки вистачить на всіх», поступово циркові трупи починали стикатися з конкуренцією, причому конкурувало це розмаїття різних видовищних мистецтв не лише з театром, а й між собою. Траплялося, що у місті майже одночасно виступав цирк, у театрі забавляли публіку акробати, а десь поблизу гостював звіринець $з$ дресированими левами і гієнами.

8) Невизначеність і суперечливість статусу. Попри те, що за критеріями визначень тогочасних естетик та енциклопедій окремі «циркові мистецтва», формально, потрапляли у категорію «красних мистецтв», інтелектуальна еліта обережно і стримано сприймала «цирк» і не робила спроб його естетичного аналізу, вочевидь, займаючи очікувальну позицію. Хоча навіть найсуворіших критиків захоплювала складність трюків і демонстрація людських надможливостей, перспективи розвитку цирку були неясними. Явище було відносно новим і ще не встигло зайняти свою нішу у системі тогочасної культури.

Вже в першій третині XIX ст., як в енциклопедіях, так і в окремих брошурах та есе, друкувалися біографії провідних виконавців. Артистичну діяльність регулювали окремі законодавчі норми, кращі вистави відвідувалися першими особами Імперії, які поділяли загальне захоплення і «освячували» циркові вистави своєю присутністю, що свідчило про високий суспільний статус циркових показів. Особливу роль у стосунках «цирку» 3 владою відігравали покази історичних пантомім, які були елементом політичного і освітнього впливу на суспільство, ці покази залучали можновладців до лав шанувальників цирку, а це, в свою чергу, забезпечувало циркам заступництво. 
Подібно до акробатів-канатоходців, «цирк» досліджуваного періоду балансував між мистецтвом, видовищем і розвагою, посідаючи помітне місце в культурному та політичному житті як Галичини, так і всієї Австро-Угорської імперії.

\section{Джерела та література}

1. Копержинський Кость. Магічно-акробатичні й пантомімічні вистави на Україні в другій половині XVIII та на початку XIX ст. Украӥна. Науковий тримісячник українознавства. Кн. 3. Київ: Державне видавництво України, 1924. C. 53-61.

2. Cyrk w świecie widowisk / pod redakcją Grzegorza Kondrasiuka. Lublin: Warsztaty Kultury w Lublinie, 2017. $484 \mathrm{~s}$.

3. «Der Telegraph». österreichisches Conversationsblatt für Kunst, Literatur, geselliges Leben, Theater, Tagsbegebenheiten, Industrie und Fabrikwesen. Wien. 1836. Nr. 30. 16.03.

4. «Der Wanderer». 1834. Nr. 293. 20.10.

5. «Der Wanderer». 1836. Nr. 4. 04.01.

6. «Der Wanderer». 1836. Nr. 8. 08.01.

7. «Der Wanderer». 1836. Nr. 20. 20.01.

8. «Der Wanderer». 1836. Nr. 81. 21.03.

9. «Der Wanderer». 1836. Nr. 174. 22.06.

10. «Der Wanderer». 1836. Nr. 197. 15.07.

11. «Der Wanderer». 1836. - Nr. 200. — 18.07.

12. «Der Wanderer». 1836. Nr. 228. 15.08.

13. «Der Wanderer». 1836. Nr. 247. 03.09.

14. «Der Wanderer». 1836. Nr. 311. 06.11.

15. «Der Wanderer». 1836. Nr. 326. 21.11.

16. «Der Wanderer». 1836. Nr. 358. 23.12.

17. «Der Wanderer». 1837. Nr. 22. 26.01.

18. Die Verschönerungen Lembergs, der Hauptstadt des österreichischen Galiziens, von 1820 bis 1829 . Von Aloys Uhle, Director der k.k. Realschule zu Lemberg. Neues Archiv für Geschichte, Staatenkunde, Literatur und Kunst. 1829. Nr. 91. 13.11. S. 716-720.

19. «Gazeta Lwowska». 1826. Nr. 35. 24.03.

20. «Gazeta Lwowska». 1842. Nr. 43. 12.04.

21. Got, Jerzy. Das österreichische Theater in Lemberg im 18. und 19. Jahrhundert: aus dem Theaterleben der Vielvölkermonarchie. Wien: Verlag der Österreichischen Akademie der Wissenschaften, 1997. 2 v. (875 s.)

22. Gubernial - Dekret vom 5. Mai 1827 Gub. Zahl 22062. Prowincjonalny Zbiór Praw Królestwa Galicyi i Lodomeryi za rok 1827. Wydany za naywyższym Rozkazom pod dozorem c.k. Galicyiskiego kraiowego Gubernium. We Lwowie: Drukiem Piotra Pillera. 507 s.

23. Hera, Janina. $Z$ dziejów pantomimy, czyli pałac zaczarowany. Warszawa: Państwowy Instytutu Wydawniczy, 1975. 409 s.

24. «Intelligenzblatt der Jenischen Allem. Literatur-Zeitung». 1808. Nr. 82. 12.11.

25. «Kunst, Literatur, Musik, Mode und geselliges Leben». Wien. 1834. Nr. 261. 31.12.

26. Lasocka, Barbara. O czarodziejach, akrobatach, panoramach. Lwów 1800-1850. Pamiętnik Teatralny: czasopismo kwartalne poświęcone historii i krytyce teatru. Tom 18 . Nu. 1/2 (69/70). 1969. S. 127-149.

27. «Lemberger allgemeiner Anzeiger». Tagesblatt für Handel und Gewerbe, Kunst, geselliges Leben, Unterhaltung und Belehrung. 1857. Nr. 67. 30.07.

28. «Lemberger Zeitung». 1818. Nr. 44. 13.04.

29. «Lemberger Zeitung». 1821. Nr. 96. 10.08.

30. «Lemberger Zeitung». 1823. Nr. 85. 18.07 .
31. «Lemberger Zeitung». 1823. Nr. 88. 25.07.

32. «Lemberger Zeitung». 1823. Nr. 90. 30.07.

33. «Lemberger Zeitung». 1825. Nr. 94. 22.08.

34. «Lemberger Zeitung». 1825. Nr. 149. 30.12.

35. «Lemberger Zeitung». 1826. Nr. 26. 03.03.

36. «Lemberger Zeitung». 1826. Nr. 35. 24.03.

37. «Lemberger Zeitung». 1826. Nr. 40. 10.04.

38. «Lemberger Zeitung». 1826. Nr. 49. 01.05.

39. «Lemberger Zeitung». 1826. Nr. 55. 17.05.

40. «Lemberger Zeitung». 1826. Nr. 58. 24.05.

41. «Lemberger Zeitung». 1826. Nr. 60. 29.05.

42. «Lemberger Zeitung». 1826. Nr. 119. 18.10.

43. «Lemberger Zeitung». 1827. Nr. 30. 14.03.

44. «Lemberger Zeitung». 1827. Nr. 51. 09.04.

45. «Lemberger Zeitung». 1830. Nr. 28. 10.03.

46. «Lemberger Zeitung». 1834. Nr. 5. 15.01.

47. «Lemberger Zeitung». 1834. Nr. 104. 12.09.

48. «Lemberger Zeitung». 1836. Nr. 24. 26.02.

49. «Lemberger Zeitung». 1836. Nr. 25. 29.02.

50. «Lemberger Zeitung». 1836. Nr. 64. 06.06.

51. «Lemberger Zeitung». 1836. Nr. 104. 12.09.

52. «Lemberger Zeitung». 1836. Nr. 107. 19.09.

53. «Mnemosyne». 1840. Nr. 33. 25.04.

54. Neuestes Conversations-Lexicon, allgemeine Deutsche RealEncyklopädie für gebildete Stände. Von einer Gesellschaft von Gelehrten ganz neu bearbeitet. Zehnter Band. (Kar-Lan). Wien: Gedruckt und verlegt von Franz Ludwig, 1829. 604 s.

55. Österreichisches Biographisches Lexikon. Der populärste Tiermimiker der Theatergeschichte: Eduard Klischnigg. [Електронний ресурс]. Режим доступу: https://www. oeaw. ac. at/fileadmin/Institute/INZ/Bio_Archiv/bio_2013_10. htm

56. «Rozmaitości» (lwowskie). «Dawne afisze lwowskie». 1840. Nr. 11. 14.03.

57. Saltarino, Signor - Artisten-Lexikon: biographische Notizen über Kunstreiter, Dompteure, Gymnastiker, Clowns, Akrobaten, Specialitäten etc.: aller Länder und Zeiten. Düsseldorf: Druck und Verlag von Ed. Lintz, 1895. 316 s.

58. Sammlung aller k.k. Gesetze vom Jahre 1740 bis 1780 . In einer chronologischen Ordnung, und sistematischen Verbindung. Wien: verlegt bei Joh. Georg Mößle k-k. privil. Buchhändler, 1787. $821 \mathrm{~s}$.

59. Schnür-Pepłowski, Stanisław. Z przeszłości Galicyi (17721862). Wydanie drugie uzupełnione. Lwów: Jakubowski \& Zadurowicz, 1895. $627 \mathrm{~s}$.

60. «Theaterzeitung und Originalblatt für Kunst, Literatur, Musik, Mode und geselliges Leben». Wien. 1834. Nr. 99. 20.05 .

61. «Theaterzeitung und Originalblatt für Kunst, Literatur, Musik, Mode und geselliges Leben». Wien. 1834. Nr. 196. 01.10 .

62. The situation of the circus in the EU Member States (Working Paper) European Parliament Education and Culture Series. 2003. - 181 р. [Електронний ресурс]. Режим доступу: http://www. europarl. europa. eu/RegData/etudes/etudes/ join/2003/326724/DG-4-CULT_ET(2003)326724_EN. pdf

63. Wiener Allgemeine Theaterzeitung. 1819. Nr. 95. 10.08 .

64. Wiener Allgemeine Theaterzeitung. 1819. Nr. 143. 20.11.

\section{References}

1. Koperzhinsky, Kost'. (1924). Magic-acrobatic and pantomime performances in Ukraine in the second half of the XVIII and the beginning of the XIX century. Kyiv: State Publishing House of Ukraine. 53-61 [in Ukrainian].

2. Kondrasiuk, G. (Eds.). (2017). The Circus in the world of the spectacles. Lublin: Workshops of Culture in Lublin, 484 [in Polish].

3. «The Telegraph». Austrian Conversations sheet for art, literature, social life, theater, day events, industry and factory. (1836). No. 30. 16.03. Vienna [in German]. 
4. «The Wanderer». (1834). Nr. 293. 20.10. Vienna [пп. 4-17in German].

5. «The Wanderer». (1836). Nr. 4. 04.01. Vienna.

6. «The Wanderer». (1836). Nr. 8. 08.01. Vienna.

7. «The Wanderer». (1836). Nr. 20. 20.01. Vienna.

8. «The Wanderer». (1836). Nr. 81. 21.03. Vienna.

9. «The Wanderer». (1836). Nr. 174. 22.06. Vienna.

10. «The Wanderer». (1836). Nr. 197. 15.07. Vienna.

11. «The Wanderer». (1836). Nr. 200. 18.07. Vienna.

12. «The Wanderer». (1836). Nr. 228. 15.08. Vienna.

13. «The Wanderer». (1836). Nr. 247. 03.09. Vienna.

14. «The Wanderer». (1836). Nr. 311. 06.11. Vienna.

15. «The Wanderer». (1836). Nr. 326. 21.11. Vienna.

16. «The Wanderer». (1836). Nr. 358. 23.12. Vienna.

17. «The Wanderer». (1837). Nr. 22. 26.01. Vienna.

18. Uhle, Aloys. (1829). The embellishments of Lemberg, the capital of Austrian Galicia, from 1820 to 1829. New Archive for History, States, Literature and Art. No. 91. 13.11. pp. 716-720. Vienna [in German].

19. «Lwowska Gazette». (1826). Nr. 35. 24.03. Lwow [in Polish].

20. «Lwowska Gazette». (1842). Nr. 43. 12.04. Lwow [in Polish].

21. Got, J. (1997). The Austrian Theater in Lviv in the 18th and 19th centuries: from the theater life of the multi-ethnic monarchy. Vienna: Publishing House of the Austrian Academy of Sciences, 875 [in German].

22. Gubernial - Decree from 5. Mai 1827. (1827). Provincial Collection of the Rights of the Kingdom of Galicia and Lodomeria for 1827. Lwow: A print by Piotr Piller, 507 [in German and Polish]

23. Hera, J. (1975). From the history of pantomime, or the enchanted palace. Warsaw: State Institute of Publishing, 409 [in Polish].

24. «Intelligence Journal of the Yenish All. Literary Newspaper». (1808). Nr. 82. 12.11. Vienna [in German].

25. «Art, literature, music, fashion and social life». (1834). Nr. 261. 31.12. Vienna [in German].

26. Lasocka, B. (1969). About wizards, acrobats, panoramas. Lviv 1800-1850. Theatrical Monument: quarterly magazine devoted to the history and criticism of the theater, Vol. 18, Number 1/2 (69/70), 127-149 [in Polish].

27. «Lemberger general Gazette». Daily newspaper for trade and commerce, art, social life, entertainment and instruction. (1857). Nr. 67. 30.07. Lemberg [in German].

28. «Lembergs Newspaper». (1818). Nr. 44. 13.04. Lemberg [пп. 28-52 - in German].

29. «Lembergs Newspaper». (1821). Nr. 96. 10.08. Lemberg.

30. «Lembergs Newspaper». (1823). Nr. 85. 18.07. Lemberg.

31. «Lembergs Newspaper». (1823). Nr. 88. 25.07. Lemberg.

32. «Lembergs Newspaper». (1823). Nr. 90. 30.07. Lemberg.

33. «Lembergs Newspaper». (1825). Nr. 94. 22.08. Lemberg.

34. «Lembergs Newspaper». (1825). Nr. 149. 30.12. Lemberg.

35. «Lembergs Newspaper». (1826). Nr. 26. 03.03. Lemberg.
36. «Lembergs Newspaper». (1826). Nr. 35. 24.03. Lemberg. 37. «Lembergs Newspaper». (1826). Nr. 40. 10.04. Lemberg. 38. «Lembergs Newspaper». (1826). Nr. 49. 01.05. Lemberg. 39. «Lembergs Newspaper». (1826). Nr. 55. 17.05. Lemberg. 40. «Lembergs Newspaper». (1826). Nr. 58. 24.05. Lemberg. 41. «Lembergs Newspaper». (1826). Nr. 60. 29.05. Lemberg. 42. «Lembergs Newspaper». (1826). Nr. 119. 18.10. Lemberg. 43. «Lembergs Newspaper». (1827). Nr. 30. 14.03. Lemberg. 44. «Lembergs Newspaper». (1827). Nr. 51. 09.04. Lemberg. 45. «Lembergs Newspaper». (1830). Nr. 28. 10.03. Lemberg. 46. «Lembergs Newspaper». (1834). Nr. 5. 15.01. Lemberg. 47. «Lembergs Newspaper». (1834). Nr. 104. 12.09. Lemberg. 48. «Lembergs Newspaper». (1836). Nr. 24. 26.02. Lemberg. 49. «Lembergs Newspaper». (1836). Nr. 25. 29.02. Lemberg. 50. «Lembergs Newspaper». (1836). Nr. 64. 06.06. Lemberg. 51. «Lembergs Newspaper». (1836). Nr. 104. 12.09. Lemberg. 52. «Lembergs Newspaper». (1836). Nr. 107. 19.09. Lemberg. 53. «Mnemosyne». (1840). Nr 33. 25.04. Lemberg [In German]

54. Newest Conversation Lexicon, general German Real Encyclopedia for educated estates. (1829). Tenth volume. (KarLan). Completely reworked by a society of scholars. Vienna: Printed and published by Franz Ludwig, 604 [in German].

55. Austrian Biographical Dictionary. The most popular animal mime in theater history: Eduard Klischnigg. URL: https://www. oeaw. ac. at/fileadmin/Institute/INZ/Bio_Archiv/bio_2013_10. htm

56. «Various Things» (Lviv). «Old Lviv posters». (1840). Nr. 11. 14.03. Lwow [in Polish].

57. Saltarino, S. (1895). Artist's dictionary: biographical notes on art riders, sculptors, gymnasts, clowns, acrobats, specialties, etc.: all countries and times. Dusseldorf: printing and publishing by Ed. Lintz, 316 [in German].

58. Collection of all Laws from 1740 to 1780 . - in a chronological order, and systematic connection. (1787). Vienna: published by Joh. Georg Mößle k-k. privil. Booksellers, 821 [in German].

59. Schnur-Peplowski, S. (1895). From the past of Galicyja (1772-1862). Lwow: Jakubowski \& Zadurowicz, 627 [in Polish].

60. «Theater newspaper and original sheet for art, literature, music, fashion and social life». (1834). Nr. 99. 20.05. Vienna [in German].

61. «Theater newspaper and original sheet for art, literature, music, fashion and social life». (1834). Nr. 196. 01.10. Vienna [in German].

62. The situation of the circus in the EU Member States (Working Paper) (2003). European Parliament Education and Culture Series. URL: http://www. europarl. europa. eu/ RegData/etudes/etudes/join/2003/326724/DG-4-CULT_ ET(2003)326724_EN.pdf [in English].

63. Vienna General Theater newspaper. (1819). Nr. 95. 10.08. Vienna [in German].

64. Vienna General Theater newspaper. (1819). Nr. 143. 20.11. Vienna [in German]. 